\title{
PENGGUNAAN TEPUNG BIJI DURIAN DAN NANGKA PADA BERBAGAI LEVEL TERHADAP KUALITAS BAKSO DAGING ITIK PETELUR AFKIR
}

\author{
${ }^{1)}$ Fernia Rismawati, ${ }^{2)}$ Permata Ika Hidayati, ${ }^{3)}$ Dyah Lestari Yulianti \\ ${ }^{1,2,3}$ Fakultas Peternakan, Universitas Kanjuruhan Malang \\ permata@unikama.ac.id
}

\begin{abstract}
ABSTRAK
Penelitian ini bertujuan untuk mengetahui penggunaan tepung biji durian dan nangka pada berbagi level terhadap kualitas bakso daging itik petelur afkir. Materi yang digunakan dalam penelitian ini daging itik petelur afkir sebagai bahan dasar pembuatan bakso, tepung biji buah durian, dan tepung biji buah nangka. Metode yang digunakan adalah percobaan lapangan dengan Rancangan Acak Lengkap (RAL) dengan 5 perlakuan dan 4 ulangan. Perlakuan yang digunakan adalah kontrol P0 (tanpa penambahan tepung biji durian atau tepung biji nangka), dan penambahan tepung P1 (5\%), P2 (10\%), P3 (15\%), P4 (20\%). Variabel yang diamati meliputi uji organoleptik dan daya susut masak. Hasil penelitian menunjukkan bahwa perlakuan penambahan kadar pati biji durian dan nangka pada tingkat signifikan $1 \%$ diperoleh hasil yang sangat signifikan $(\mathrm{P}<0,01)$ sehingga hipotesis diterima, yang berarti ada pengaruh penambahan tingkat pati. Penelitian ini menyimpulkan bahwa penggunaan tepung biji durian dan nangka 5\% memiliki tingkat kesukaan tertinggi dan $20 \%$ memiliki tingkat kesukaan terendah.

Kata kunci : tepung biji durian, tepung biji nangka, itik petelur afkir.

\section{Abstract}

The research was aimed to test the use of durian and jackfruit seeds at various levels on the quality of duck laying duck meatballs.This research was conducted on 20 November 2016 until 20 December 2016. The method used was field experiment in a Completely Randomized Design (CRD) with 5 treatments and 4 replications. The treatment used is P0 Control (without the addition of durian seed flour or jackfruit seed flour), and addition of flour P1 (5\%), P2 (10\%), P3 (15\%), and P4 (20\%).The material used is durian seed flour, jackfruits seed flour, and laying duck laying. The observed variables include the organoleptic test and shrinking power.The results showed that treatment of the addition of seed starch level of durian and jackfruit at significant level of $1 \%$ obtained very significant results $(\mathrm{P}<0,01)$ so that the hypothesis is accepted, which means there is an influence on the addition of starch level. This research concluded that the use of durian and jackfruit flour 5\% level has the highest level of favorite and the level of $20 \%$ has a low level of favorite.

Key words : durian seed meal, jackfruit seed flour, laying ducks laying.
\end{abstract}

\section{Pendahuluan}

Bakso merupakan salah satu produk olahan daging yang sangat terkenal dan digemari oleh semua lapisan masyarakat, yang bisa diharapkan sebagai sumber pangan yang cukup bergizi (Widati et al. 2012). Produk olahan bakso pada umumnya menggunakan bahan baku daging dan tepung. Daging yang biasanya dipakai adalah daging sapi, ayam dan ikan, sedangkan tepung yang biasanya dipakai yaitu tepung tapioka (Kusnadi et al. 2012). Data survey yang dilakukan Creative Data Make Investigationand Research (CDMI) menunjukan di Indonesia konsumsi tepung tapioka meningkatkan rata-rata 10\% pertahun. Pada tahun 2013 konsumsi tepung tapioka mencapai 3.33 juta ton, sedangkan produksi tepung tapioka di Indonesia hanya sekitar 1.2 juta ton. Hal ini memaksa Indonesia untuk melakukan impor tepung tapioka untuk memenuhi kebutuhan tersebut. 
Tepung biji durian memiliki kesamaan dengan tepung tapioka yaitu memiliki kandungan pati yang terdiri atas amilosa $22 \%$ dan amilopektin $66.33 \%$, sehingga dapat dikombinasikan dengan tepung tapioka sebagai bahan pengisi makanan (Ageng et al. 2013). Biji nangka juga merupakan sumber mineral yang baik. Selain dapat dimakan dalam bentuk utuh, biji nangka dapat diolah menjadi tepung pengganti tepung tapioka sebagai bahan pengisi bakso daging sapi ( Arna Diah, 2011).

Daging itik afkir dapat dimanfaatkan sebagai sumber protein dan lemak hewani, juga memiliki kandungan kalori relatife lebih rendah serta kandungan vitamin B lebih tinggi dibandingkan daging unggas lainnya (Smith, D. M. 2001) Dalam rangka meningkatkan konsumsi daging itik afkir, daging itik dapat diolah dengan cara dimasak, digoreng, dipanggang, dan dapat diolah menjadi produk olahan lainnya yang menarik dan lebih bervariasi untuk dikonsumsi masyarakat seperti bakso daging itik petelur. Oleh karena itu, diperlukan inovasi makanan jajanan yang sehat dan bernilai gizi tinggi dengan pembuatan bakso daging itik dengan modifikasi biji durian sebagai bahan pengikat dan subtitusi tepung tapioka.

\section{Materi Dan Metode}

Materi yang digunakan adalah daging itik petelur afkir sebagai bahan dasar dalam pembuatan bakso yang berkualitas baik, karena kualitas daging sangat berpengaruh besar dalam menghasilkan bakso yang baik. Daging itik untuk penelitian ini di dapat dari peternak itik petelur di Desa Singgahan Sanankerto Turen Malang. Tepung yang digunakan untuk bahan pengisi yaitu tepung biji buah durian dan tepung biji buah nangka yang di dapat dari toko buah pinggir jalan di Dinoyo Malang. Setelah membeli biji buah durian dan biji buah nangka kemudian biji tersebut diolah menjadi tepung.

Metode yang digunakan dalam penelitian ini adalah eksperimental laboratorium berdasarkan rancangan acak kelompok yang terdiri atas 2 variabel bebas meliputi 2 jenis tepung yang dikelompokkan terhadap variabel terikat terdiri dari 5 level penambahan tepung dan 15 ulangan sehingga total percobaan adalah 150 unit percobaan. Perlakuan terdiri dari perlakuan tepung biji durian dan nangka serta perlakuan eksperimental dengan berbagai level penambahan tepung yang berbeda dengan interval $5 \%$ pada masing masing perlakuan. Perlakuan yang diuji sebagaimana pada tabel 1.

\section{Variabel Penelitian}

Variabel yang diamati dalam penelitian ini meliputi variabel bebas yaitu level tepung durian dan tepung nangka, sedangkan untuk variabel terikat, yaitu uji organoleptik dan daya susut masak. 
Tabel 1. Diagram rancangan percobaan.

\begin{tabular}{lr}
\hline Faktor A (Jenis Tepung) & Faktor B (Level penambahan tepung) \\
\hline & $0 \%$ \\
Tepung & $5 \%$ \\
Biji & $10 \%$ \\
Durian & $15 \%$ \\
& $20 \%$ \\
\hline & $0 \%$ \\
Tepung & $5 \%$ \\
Niji & $10 \%$ \\
& $15 \%$ \\
\hline
\end{tabular}

Keterangan : Diulang sebanyak 15 kali.

Data yang diperoleh selama pengamatan dianalisis dengan menggunakan metode analisis sidik ragam ganda (Anova Univariate) dengan bantuan aplikasi SPSS for Windows22.0. Apabila pada hasil analisa menunjukkan adanya perbedaan pada perlakuan maka dilanjutkan dengan uji Duncan. Data yang digunakan dianalisis secara deskriptif dengan memaparkan semua data yang diperoleh selama penelitian. Semua data yang diperoleh dijelaskan dalam laporan sesuai dengan hasil pengamatan kemudian dibandingkan dengan teori yang ada.

\section{Hasil Dan Pembahasan}

Berdasarkan hasil analisis data terhadap penggunaan tepung biji durian dan nangka pada berbagai level terhadap kualitas bakso daging itik petelur afkir ditinjau berdasarkan variasi penambahan level tepung $0 \%, 5 \%, 10 \%, 15 \%$ dan $20 \%$, menunjukkan bahwa penambahan level tepung biji durian dan nangka pada taraf signifikan $1 \%$ didapatkan hasil sangat signifikan $(\mathrm{P}<0,01)$ sehingga dengan demikian hipotesis diterima, yang berarti terdapat pengaruh pada penambahan level tepung biji buah durian dan biji buah nangka dengan berbagai level $(0 \%, 5 \%, 10 \%, 15 \%$, dan 20\%) pemberian tepung.

Berdasarkan hasil penelitian ini telah terbukti bahwa penambahan level tepung memberikan perbedaan yang sangat nyata pada taraf signifikan $1 \%$ terhadap kualitas bakso daging itik petelur afkir, sehingga perlu dilanjutkan dengan uji Duncan. Hasil uji duncan pengaruh level tepung biji durian terhadap rata-rata uji organoleptik bakso daging itik petelur afkir pada Tabel 2. 
Tabel 2. Hasil uji duncan pengaruh level tepung biji durian terhadap rata-rata uji organoleptik bakso daging itik petelur afkir

\begin{tabular}{lccccc}
\hline Level & Kekenyalan & Aroma & Rasa & Warna & Tekstur \\
\hline $0 \%$ & $3,87 \pm 0,78^{\mathrm{bc}}$ & $4,00 \pm 0,52^{\mathrm{cd}}$ & $3,93 \pm 0,52^{\mathrm{c}}$ & $4,00 \pm 0,45^{\mathrm{c}}$ & $3,77 \pm 0,57^{\mathrm{c}}$ \\
$5 \%$ & $4,00 \pm 0,79^{\mathrm{c}}$ & $4,17 \pm 0,59^{\mathrm{d}}$ & $4,03 \pm 0,55^{\mathrm{c}}$ & $3,87 \pm 0,50^{\mathrm{c}}$ & $3,63 \pm 0,56^{\mathrm{c}}$ \\
$10 \%$ & $3,53 \pm 0,73^{\mathrm{bc}}$ & $3,78 \pm 0,62^{\mathrm{bc}}$ & $3,70 \pm 0,59^{\mathrm{bc}}$ & $3,53 \pm 0,78^{\mathrm{bc}}$ & $3,17 \pm 0,70^{\mathrm{b}}$ \\
$15 \%$ & $3,43 \pm 0,68^{\mathrm{b}}$ & $3,40 \pm 0,62^{\mathrm{ab}}$ & $3,40 \pm 0,72^{\mathrm{ab}}$ & $3,23 \pm 0,90^{\mathrm{ab}}$ & $2,97 \pm 0,85^{\mathrm{ab}}$ \\
$20 \%$ & $2,93 \pm 0,69^{\mathrm{a}}$ & $3,13 \pm 0,78^{\mathrm{a}}$ & $3,03 \pm 0,85^{\mathrm{a}}$ & $2,90 \pm 0,84^{\mathrm{a}}$ & $2,63 \pm 0,85^{\mathrm{a}}$ \\
\hline Sig. & 0,00 & 0,00 & 0,00 & 0,00 & 0,00 \\
\hline
\end{tabular}

Berdasarkan Tabel 2 data hasil uji organoleptik dari 15 orang panelis terhadap kekenyalan, aroma, rasa, warna dan tekstur bakso daging itik petelur afkir dengan menggunakan tepung biji durian dan tepung biji nangka tertinggi pada pemberian level 5\% sedangkan terendah pada level 20\%. Semakin banyak di tambah tepung biji durian dan tepung biji nangka maka hasil bakso semakin lembek hal ini terjadi karena tepung biji durian dan tepung biji nangka memiliki kandungan pati yang terdiri atas amilosa $22 \%$ dan amilopektin 66,33\%. Amilosa di dalam tepung bersifat keras dan peran dalam membentuk gel sedangkan amilopektin dapat menyebabkan sifat lengket. Berdasarkan penelitian dari Nurfiana F, Mukaromah, U, Jeannisa FC. Putra S. (2009) menyatakan bahwa kadar air, kadar protein, karbohidrat dan kadar lemak tepung biji durian dan tepung biji nangka sama dengan tepung tapioka dan masih memenuhi syarat mutu SNI 01-6683-2002. Sehingga tepung biji durian dan tepung biji nangka dapat digunakan sebagai bahan untuk pembuatan bakso.

Tabel 3. Hasil pengaruh interaksi tepung dan level terhadap daya susut masak bakso daging itik petelur afkhir

\begin{tabular}{lr}
\hline Level & Daya Susut Masak (\%) \\
\hline $0 \%$ & $0,89 \pm 0,51$ \\
$5 \%$ & $0,54 \pm 0,45$ \\
$10 \%$ & $0,67 \pm 0,36$ \\
$15 \%$ & $0,58 \pm 0,34$ \\
$20 \%$ & $0,82 \pm 0,30$ \\
\hline Sig & 0,143 \\
\hline
\end{tabular}

Berdasarkan data pada Tabel 3 dapat dijelaskan bahwa daya susut masak pada bakso daging itik petelur afkir tepung biji durian dan tepung biji nangka berpengaruh tidak nyata $(\mathrm{P}>0,05)$ dengan dayat susut masak tertinggi pada level $20 \%$ mencapai $0,82 \%$ dan terendah pada level $5 \%$ mencapai $0,54 \%$. Bakso daging itik tepung biji durian dan tepung biji nangka mempunyai rata-rata nilai susut masak tertinggi, karena kandungan amilopektin yang cukup tinggi pada pati biji durian dan biji nangka akan membentuk 
susunan matriks yang lemak dengan air pada bakso daging itik selama proses gelatinisasi, sehingga kandungan air bebas pada bakso banyak yang keluar pada saat pemanasan. Hal ini sesuai dengan pendapat Wibowo (2006), susut masak sangat dipengaruhi oleh hilangnya air selama pemasakan, keadaan ini dipengaruhi oleh protein yang dapat mengikat air, semakin banyak air yang ditahan oleh protein maka semakin sedikit air yang keluar sehingga susut masak berkurang. Susut masak dipengaruhi pula oleh daya ikat air. Daya ikat air menurun dengan substitusi tepung biji durian dan tepung biji nangka, sehingga susut masak bakso daging itik meningkat. Pati biji durian dan biji nangka tidak dapat mengikat air bebas secara sempurna di dalam bakso sehingga kandungan air bebas banyak yang keluar pada saat pemasakan.

\section{Kesimpulan}

Berdasarkan hasil penelitian dapat hasil uji organoleptik penggunaan tepung biji durian dan tepung biji nangka pada level 5\% memiliki tingkat kesukaan tertinggi dan level 20\% memiliki tingkat kesukaan terendah. Dan hasil uji daya susut masak tertinggi pada level $20 \%$ sedangkan terendah pada level $10 \%$.

\section{Daftar Pustaka}

Ageng PM. 2013. Djalal R, Eny SW. Pengaruh penambahan biji durian terhadap kualitas kimia dan organoleptik nugget ayam. Jurnal ilmu-ilmu peternakan 23 (3): 17-26. [BPS] Badan Pusat Statistik.

Arna Diah.2011 .Pemanfaatan Biji Nangka Pada Pembuatan Bakso. Universitas Negeri Surabaya.

Kusnadi DC, Bintoro VP, Al- Baarri AN. 2012. Daya ikat Air, tingkat kekenyalan dan kadar protein pada bakso kombinasi daging sapi dan daging kelinci. Jurnal Aplikasi Teknologi Pangan 1(2):28-31.

Nurfiana F, Mukaromah, U, Jeannisa FC. Putra S. 2009. Pembuatan bioethanol dari biji durian sebagai sumber energi alternatif [prosiding]. Seminar Nasional VSDM Teknologi Nuklir Yogyakarta, 5 November 2009.

Smith, D. M. 2001. Functional properties of muscle proteins in processed poultry product. In: Sams, A. R. (Ed.). Poultry Meat Processing. CRC Press. USA.

Wibowo S. 2006, Pembuatan Bakso Ikan dan Bakso Daging. Jakarta : PT Penebar Swadaya.

Widati AS, Eny SW, Rulita, Muhammad SZ. 2012. The effect of addition tapioca starcton quality of chiken meatball chips whit facuum frying method. Jurnal Ilmu-ilmu Peternakan 21(2): 11-27.. 